\title{
Article
}

\section{The Living Archive in the Anthropocene}

\author{
Nora Almeida and Jen Hoyer
}

\section{ABSTRACT}

This paper presents the concept of the living archive as a system which reflects how social behavior and cultural production are part of the Anthropocene. The authors explore how dominant narratives of both the Anthropocene and the archive work to consolidate power and maintain cultural and disciplinary divisions. The authors refute conceptions of the Anthropocene as a purely biophysical phenomenon that is alienated from cultural practice and of the archive as a comprehensive and nostalgic space. They then introduce the living archive as an alternative representational, creative, and reactive space and illustrate how the living archive can intervene in ecological reality. Finally, the authors explore how the concept of the living archive is enacted and invoked by the practices of the Interference Archive, an independent community archive in Brooklyn, New York. 
It is the future which is at issue here, and the archive as an irreducible experience of the future. ${ }^{1}$

\section{INTRODUCTION}

In this paper, we explore the relationship between the archive and the Anthropocene and consider how a conceptual reframing of archival and anthropocenic narratives might enable new possibilities for cultural, economic, socio-political, and ecological futures. The Anthropocene is a word that at once designates a new geologic era, "signals the current moment of mass extinctions and climate change resulting from human activities, and serves as a convenient, conceptual 'boundary object' that describes (in a word) a whole epoch." ${ }^{2}$ As we examine writing about the Anthropocene, we hear eerie echoes of voices that have theorized the archive and we uncover parallel narratives that consolidate power, reify human exceptionalism, and create political inertia. While the narrative that explains both the Anthropocene and the archive-a narrative voiced by the white, western academy-usually does not associate the two, we will unpack these concepts together in order to understand and reconsider them through their similarities. We see immediate parallels as the Anthropocene is understood primarily through an engagement with material history (i.e., the artifacts the archive preserves). Exploring further, we recognize that the work of producing ecological and socio-political futures involves excavating history and interrogating systems of power. Consequently, in ways large and small, the work of defining the archive, its mission, and its contents is also the work of imagining and shaping our understanding of ourselves in the Anthropocene.

The archive occupies a paradoxical position in that it both creates and is subject to the Anthropocene and its conditions. ${ }^{3}$ The task of reconsidering the archive as we confront the Anthropocene is daunting; it requires an interrogation of archival theory and a gradual transformation of systems and spaces that are both materially and temporally

\footnotetext{
${ }^{1}$ Jacques Derrida, Archive Fever: A Freudian Impression (Chicago, IL: The University of Chicago Press, 1996), 45.

2 Jamie Lorimer, "The Anthropo-Scene: A Guide for the Perplexed," Social Studies of Science 47, no. 1 (2017): 118.

${ }^{3}$ Environmental humanist Jesse Oak Taylor explores parallels between the Anthropocene and archives and presents ice-core samples as a form of "atmospheric archive" that "enables and delimits" what exists. Of course, the conditions of the atmosphere (and thus of the archive) are shaped by the same entities - people, events, natural phenomena - that it contains. Taylor's atmospheric archive thus offers us a glimpse of the strange mutuality that humans share with the systems (ecological, informational, and socio-political) that they create and are subject to. Jesse Oak Taylor, "Auras and Ice Cores: Atmospheric Archives and the Anthropocene," Minnesota Review 83, no. 1 (2014): 73-75.
} 
exponentially larger than us. ${ }^{4}$ The work of reimagining the archive is also continually threatened by the interest of authorities and those who wield political and economic power, by entrenched and oppressive institutional realities, by rising seas and changing climates, by the consolidation of economic and cultural capital, and by the weight of its own cultural conception.

In spite of these limitations, we aim to outline an archival framework that helps us confront a new ecological reality. We imagine an archive that defines itself primarily in relationship to lived community practices and dynamic sites of cultural and creative production. Building upon and expanding past uses of the term, we introduce a "living archive" that moves beyond the legacy of institutional structures and processes; is enacted through a participatory, place-based strategy; and is affirmative and generative. We recognize our limitations in doing this work as white women with graduate degrees (and in the context of Anthropocene scholarship as disciplinary outsiders). We write from within and against these positions and acknowledge that our roles-as volunteers at the archive we explore in our case study and as information professionals-color how we view and present the living archive framework.

In an effort to confront the paradox of advocating for moving archival and Anthropocenic narratives beyond academic theorizing in this theoretical academic space, we want to present key concepts in ways that are both accessible and subversive. Following a critique of Anthropocenic and archival narratives, we present a theory of the "living archive" through a case study integrated with principles extrapolated from a collaboratively written manifesto. We intend for this living archive manifesto ${ }^{5}$ to serve as an artifact that can live and change beyond the confines of this essay as it comes in contact with new archival contexts and communities. The living archive as defined through our manifesto is not just a theoretical negotiation; it builds on our experience working in a community archive in Brooklyn, New York, and emerges as a direct confrontation to the limits of oppressive structures and consolidation of capital that we see as real threats to archives today. And, it is expressed using a form - the manifestothat has historically been used to activate change.

\footnotetext{
4 Joanne Evans et al., "Self-determination and Archival Autonomy: Advocating Activism," Archival Science 15, no. 4 (2015): 347.

${ }^{5}$ See Appendix 1 for manifesto.
} 


\section{REFLECTIONS FROM THE ANTHROPOCENE}

\section{Origins of a Scientific Term}

The 2002 publication of the article "Geology of Mankind" 6 in Nature by Geologist Paul Crutzen and the subsequent introduction of the term "Anthropocene" into contemporary scientific and political discourse became something like the fact of climate change itself: incontrovertible, irreparable, and inescapable. In the Anthropocene, we found a name that seemed to capture the existential scope and ecological extent of the impact of human activity on earth systems. ${ }^{7}$ While the introduction of the Anthropocene into public consciousness reflected a consensus that we are living in a "human-dominated, geological epoch," ${ }^{8}$ debates about what the Anthropocene means as a theoretical construct and geologic marker and what the Anthropocene means to us in terms of our moral and sociopolitical responsibility has since been the subject of extensive debate. The lack of consensus about what the Anthropocene means, the socio-political reality it reflects, and the future it signifies are not just questions that reflect theoretical differences but also political and disciplinary ones. Disagreement about the ontological and socio-political implications of the Anthropocene is a symptom of the conflation of narratives about the Anthropocene as epoch and the Anthropocene as a larger environmental, socio-political, and cultural phenomenon. ${ }^{9}$ Some scientists believe the solution is to disarticulate the (capital "A") Anthropocene epoch from broader, murkier anthropocene(s) that have preoccupied social scientists and humanists, while others argue that the process of defining the epoch must include input from social scientists and humanists. ${ }^{10}$

${ }^{6}$ Paul J. Crutzen, "Geology of Mankind," Nature 415, no. 6867 (2002): 23.

7 Jan Zalasiewicz et al., "Are We Now Living in the Anthropocene?," GSA Today 18, no. 2 (2008); Dipesh Chakrabarty, "The Climate of History: Four Theses," Critical inquiry 35, no. 2 (2009): 197-222; Robert Davis, and David Oldroyd, "Inventing the Present: Historical Roots of the Anthropocene," Earth Sciences History 30, no. 1 (2011): 63-84.

${ }^{8}$ Crutzen, "Geology of Mankind," 23; Michael A. Ellis, and Zev Trachtenberg, "Which Anthropocene is it to Be? Beyond Geology to a Moral and Public Discourse," Earth's Future 2, no. 2 (2014): 122-125; Clive Hamilton, "Getting the Anthropocene so Wrong," The Anthropocene Review 2, no. 2 (2015): 102-107. See also: Bruno Latour, "Anthropocene Lecture" (lecture, Haus der Kulturen der Welt, Berlin, Germany, May 4, 2018), https://www.youtube.com/watch?v=UtaEJo-jo8Q.

${ }^{9}$ Simon L. Lewis and Mark A. Maslin, "A Transparent Framework for Defining the Anthropocene Epoch," The Anthropocene Review 2, no. 2 (2015): 128-146; Hamilton, "Getting the Anthropocene so Wrong."

${ }^{10}$ Erle Ellis, Mark Maslin, Nicole Boivin, and Andrew Bauer. "Involve Social Scientists in Defining the Anthropocene," Nature News 540, no. 7632 (2016): 192. 


\section{What's in a Name: The Dominant Narrative}

Regardless of disciplinary or political positioning, in the Anthropocene we are all quite sure that whatever we used to mean by "nature" is no longer adequate to describe a world in which, "age-old humanist distinction between natural history and human history" are collapsed. ${ }^{11}$ While most scientists and humanists agree that the Anthropocene "radically unsettles the philosophical, epistemological and ontological ground on which the natural sciences, social sciences, and humanities have traditionally stood," 12 there is less consensus across disciplines about the implications of the "end of nature"13 in terms of what future socio-political and economic systems should look like and by what process they should be produced.

Much of the scientific literature about the Anthropocene within the field of Earth Systems Science (ESS), where the term originated, ${ }^{14}$ is preoccupied with pinpointing and debating its origin. In this disciplinary arena, the concept formally refers to a formal geologic era authored by humans but not yet officially designated by the International Commission on Stratigraphy's Anthropocene Working Group (AWG). ${ }^{15}$ Some ESS scholars trace its beginning to the advent of agriculture, or, further back, to the last ice-age, or to the age of the steam engine, or the advent of colonialism, or to the detonation of the first atomic bomb. ${ }^{16}$ Within the ESS narrative, this emphasis on time has to do with the fact

${ }^{11}$ Thesis 1 in Chakrabarty, "The Climate of History: Four Theses." See also: Latour, "Anthropocene Lecture."

12 Jeremy Baskin, "Paradigm Dressed as Epoch: The Ideology of the Anthropocene," Environmental Values 24, no. 1 (2015): 18.

13 Jamie Lorimer, "Multinatural Geographies for the Anthropocene," Progress in Human Geography 36, no. 5 (2012): 597.

${ }^{14}$ For more on the history of epochal designation including discussions of the conceptual foundations for epochal shift in the field of geography, see Robert Davis, "Inventing the Present: Historical roots of the Anthropocene." Earth Sciences History 30, no. 1 (2011): 63-84. Davis traces Cruzten's use of the term "Anthropocene" to its appearance in a 2000 newsletter which Cruzten co-authored with Eugene F. Stoermer, but the 2002 publication in Nature is more frequently cited as the source of the entry of the term into the cultural lexicon.

15 Ian Angus, "Anthropocene Working Group: Yes, a New Epoch has begun," Climate and Capitalism, January 9, 2016. https://climateandcapitalism.com/2016/01/09/anthropoceneworking-group-yes-a-new-epoch-has-begun/.

${ }^{16}$ Will Steffen et al., "The Anthropocene: Conceptual and Historical Perspectives," Philosophical Transactions of the Royal Society of London A: Mathematical, Physical and Engineering Sciences 369, no. 1938 (2011): 847; Lorimer, "The Anthropo-Scene: A Guide for the Perplexed"; Tero Toivanen et al., "The Many Anthropocenes: A Transdisciplinary Challenge for the Anthropocene Research," The Anthropocene Review 4, no. 3 (2017): 183-198; Christophe Bonneuil and Jean-Baptiste Fressoz, The Shock of the Anthropocene: The Earth, History and Us (New York: Verso Books, 2016). 
that geologic boundary definitions arise out of formal, disciplinary-specific processes of identifying markers within rock strata which can take millions of years to form. ${ }^{17}$ The small amount of attention given within this field to potential responses to emerging social, economic, political, and environmental problems have focused almost exclusively on the application of scientific knowledge.

While the research landscape of the Anthropocene is complex and increasingly interdisciplinary, the ESS narrative often overshadows contributions from social science and humanities scholars. This dominant Anthropocene narrative disproportionately focuses on biological indicators rather than the socio-political and economic roots of ecological change, ${ }^{18}$ disguises the "unequal effects" and causes of climate change, ${ }^{19}$ and advances techno-biological and industry-focused solutions to address what are ultimately complex (and intertwined) ecological, political, economic, and social issues. ${ }^{20}$

\section{Politics of the Anthropocene}

If the ESS narrative seems to be "disarticulated from social processes" ${ }^{21}$ and political realities that contribute and respond to environmental change, this doesn't mean that the ESS framing of Anthropocene doesn't have important socio-political implications. ${ }^{22}$ There are legitimate "intellectual, epistemic, personal and institutional reasons why geoscientists are interested in whether we end up in a new epoch or age, or whether we are offered a flexible, informal diachronic label." ${ }^{23}$ Naming can "legitimize extant power relationships" ${ }^{24}$ and there are signs that the ESS narrative is being interpreted and strategically used to advocate for "normative prescriptions of planetary management" 25

\footnotetext{
${ }^{17}$ Lewis and Maslin, "A Transparent Framework for Defining."

18 Julia Adeney Thomas, "History and Biology in the Anthropocene: Problems of Scale, Problems of value," The American Historical Review 119, no. 5 (2014): 1587-1607.

${ }^{19}$ Eric S. Godoy and Aaron Jaffe, "We Don't Need a 'War' on Climate Change, We Need a Revolution," [Op-ed] New York Times, October 31, 2016, https://www.nytimes.com/2016/10/31/opinion/we-dont-need-a-war-on-climate-change-weneed-a-revolution.html; See also: Baskin, "Paradigm Dressed as Epoch," 16; Lövbrand et al., "Who Speaks for the Future of Earth?" 216.

${ }^{20}$ Andreas Malm and Alf Hornborg, "The Geology of Mankind? A Critique of the Anthropocene Narrative." The Anthropocene Review 1, no. 1 (2014): 62-69; Baskin, "Paradigm Dressed as Epoch."

${ }^{21}$ Karen O'Brien and Jon Barnett, "Global Environmental Change and Human Security," Annual Review of Environment and Resources 38 (2013): 374.

${ }^{22}$ Eva Lövbrand et al., "Who Speaks for the Future of Earth? How Critical Social Science Can Extend the Conversation on the Anthropocene," Global Environmental Change 32 (2015): 216.

${ }^{23}$ Lorimer, "Multinatural geographies for the Anthropocene," 131.

${ }^{24}$ Davis and Oldroyd, "Inventing the Present: Historical Roots of the Anthropocene," 63.

${ }^{25}$ Baskin, "Paradigm Dressed as Epoch," 18.
} 
and to justify prevailing political and economic systems. ${ }^{26}$ This is not to suggest that scientists (in ESS and beyond) "can't help us understand our political predicament" ${ }^{27}$ and the potential ecological futures that will result from political decisions, but because they have been "kidnapped by epistemology" ${ }^{28}$ and trapped within disciplinary silos, "they cannot provide the political imagination to resolve it." 29

Within social science and humanities scholarship about the Anthropocene, the focus has been on the need for interdisciplinary, forward-looking, culturally-situated, and politically aware discussions of what the Anthropocene means and how we can respond to it. ${ }^{30}$ The emphasis here is on an Anthropocene discourse that considers the full scope of socio-political and economic forces that have contributed to ecological problems. Attempts to reinsert the "displaced" ${ }^{31}$ Anthropocene into a broader conversation about ethics, community, history, and human (and non-human) agency might be achieved through critical processes that "denaturalize present conditions and expand our thinking about possible options." 32 While we may "have no choice but to live in an Anthropocene," ${ }^{\prime 33}$ we still, some social scientists and humanists believe, have the capacity to make political and social decisions that will dictate what "life in the ruins" ${ }^{34}$ will look like. While this narrative represents a departure from the ESS anthropocenic framing, other social scientists and humanists posit that discussions which foreground human agency in shaping planetary futures (whether the emphasis is primarily on geo-technical or political solutions) overshadow the fact of "humanity's material dependence, embodiment and fragility." 35

For all of the important work the social science / humanist critique has done to change the dynamics and scope of the Anthropocene narrative, it rarely gets as far as imagining possible futures. Rather than articulating paths to new socio-political and

${ }^{26}$ Ellis and Trachtenberg, "Which Anthropocene is it to Be?" 122-125; John Bellamy Foster, "Trump and Climate Catastrophe," Monthly Review 68, no. 9 (2017): 1-17.

27 Thomas, "History and Biology in the Anthropocene: Problems of Scale, Problems of Value," 1605.

${ }^{28}$ Latour et al., "Anthropologists Are Talking-About Capitalism, Ecology, and Apocalypse," Ethos 83, no. 3 (2018): 594.

${ }^{29}$ Thomas, "History and Biology in the Anthropocene: Problems of Scale, Problems of Value," 1605.

${ }^{30}$ A growing number of scholars publishing on the Anthropocene are working in blurred disciplinary arenas like eco-humanism, critical geography, and critical zone studies.

31 Malm and Hornborg. "The Geology of Mankind?" 65.

32 Thomas, "History and Biology in the Anthropocene: Problems of Scale, Problems of Value," 1605.

${ }^{33}$ Ellis and Trachtenberg, "Which Anthropocene is it to Be?"124.

${ }^{34}$ Latour, et al. "Anthropologists Are Talking - About Capitalism, Ecology, and Apocalypse."

35 Lövbrand et al., "Who Speaks for the Future of Earth?" 213. 
economic systems, "the debate has now shifted to the dialectics of nature and society itself." ${ }^{36}$ Beyond the central problem of the "anthropos" in Anthropocene, ${ }^{37}$ some theorists question whether we can articulate solutions to anthropocenic conditions before unpacking the "ethical questions opened up" and "fully identifying the nature and meaning of the problem." ${ }^{38}$ While social scientists and humanists are interested in analyzing relationships between humans and socio-political, economic, and ecological reality, discourse about the Anthropocene largely remains in a highly abstract realm and revolves around questions like: is it ontologically possible to consider biotic and abiotic forms as discrete units; what kind of "agent" are we in this paradigm; and should the age be characterized as post-natural or post-human (and what are the socio-political implications of such characterizations)? The "philosophical difficulty" of this narrative results in a feeling of "political impotence" by those who can engage with it. ${ }^{39}$

\section{Contestation: Research and Capital ${ }^{40}$}

Capitalism plays a role in both interpreting and advancing the Anthropocene narrative in its own favor and also, a few layers down, delimits the kinds of research we conduct and who has access (and the capacity to contribute) to critical conversations. Capitalism is an "imagination killer" in that it serves to separate us "from what makes [us] alive, a condition in which [we] also stop thinking, imagining, and noticing particular beings and relations." 41 The effect is a "double narrowing" of "what kind of people are important and what kind of knowledge is important" ${ }^{42}$ and this is confirmed not only by economic stratification or the consolidation of power but also, by the insular sites where conversations about the Anthropocene takes place: within disciplinary silos, in academic terms, in the West, and often, behind paywalls. It is from within a capitalist, institutionally dictated framework that we (in both the literal and universal sense) live and write as evidenced by anti-capitalist, counter-institutional narratives that cannot be articulated

\footnotetext{
${ }^{36}$ John Bellamy Foster, "Marxism in the Anthropocene: Dialectical Rifts on the Left," International Critical Thought 6, no. 3 (2016): 395.

37 Jedediah Purdy, After Nature: A Politics for the Anthropocene (Cambridge, MA: Harvard University Press, 2015).

38 Baskin, "Paradigm Dressed as Epoch," 26.

${ }^{39}$ Latour, "Anthropocene Lecture."

${ }^{40}$ For more on the relationship between capital and ecology, see: Jason W. Moore, Capitalism in the Web of Life: Ecology and the Accumulation of Capital (New York: Verso Books, 2015); Ian Angus, Facing the Anthropocene: Fossil Capitalism and the Crisis of the Earth System (New York: NYU Press, 2016).

${ }^{41}$ Latour et al., "Anthropologists Are Talking-About Capitalism, Ecology, and Apocalypse," 590.

42 Ibid.
} 
except in relation to these terms, a paradox that is an appropriate mirror for ecology described in relation to "anthropos." 43

Capitalism produces a geography of inequity that has implications for individuals' social and political agency. The "globalized technological systems" through which, some believe, we might address or mitigate the effects of climate change, "represent an unequal exchange of embodied labour and land in the world system." ${ }^{44}$ Yet it is not those who are disenfranchised and politically oppressed by "globalized technological systems" who voice this critique. The pervasiveness (and insidiousness invisibility) of inequity is demonstrated by the fact that critiques like this are voiced by scholars and published in academic journals that people outside affluent institutions cannot even access, let alone read. Capitalism (and its neoliberal institutional and professional manifestations) plays a central role in shaping what we know and how knowledge is shared since, "we construct those technologies that we think are important for examining a particular perspective of nature" 45 and what 'we think is important' is, more frequently than not, foreclosed by western institutional cultures and the availability of research funding.

Some scholars have suggested that the Anthropocene concept has been helpful in creating cross-disciplinary conversations. However, academic culture and the pressure to produce and publish research might result in "epistemological terrors" for scientists and humanists alike who "get into the same kinds of panic over what kinds of professional stakes they would have in [interdisciplinary collaborative research]." ${ }^{46}$ Given this reality, without both radical social and institutional transformations, it seems unlikely that we can create true cross-disciplinary dialogue. ${ }^{47}$

Capitalism figures centrally in research that positions "ecological crisis [...] as the basis of economic crisis" 48 but also, conversely, in research that highlights the role of global economics (and extractive industrialization) as a "neo-colonial" agent that has resulted in ecological destruction and economic oppression. ${ }^{49} \mathrm{~A}$ radical transformative politics that imagines alternative socio-economic and ecological futures is threatened, always, by "entrenched interests" that "perceive such necessary changes as a danger not only to the immediate prospects for accumulation, and to their own positions of power,

\footnotetext{
${ }^{43}$ Elmar Altvater et al., Anthropocene or Capitalocene?: Nature, History, and the Crisis of Capitalism (Oakland, CA: PM Press, 2016), 10.

44 Malm and Hornborg. "The Geology of Mankind?" 64.

${ }^{45}$ Scott F. Gilbert, Jan Sapp, and Alfred I. Tauber, "A Symbiotic View of Life: We Have Never Been Individuals," The Quarterly Review of Biology 87, no. 4 (2012): 326.

${ }^{46}$ Latour, et al., "Anthropologists Are Talking-About Capitalism, Ecology, and Apocalypse," 598.

${ }^{47}$ Ellis and Trachtenberg, "Which Anthropocene Is It to Be? Beyond Geology to a Moral and Public Discourse," 124.

${ }^{48}$ Foster, "Marxism in the Anthropocene: Dialectical Rifts on the Left," 405.

${ }^{49}$ Latour, "Anthropocene Lecture."
} 
but also to the very existence of capitalism-whose importance, in their accounting, outweighs that of the climate itself." 50

What does it mean if Anthropocene narratives are largely inaccessible to the people who are most likely to be affected by, displaced by, erased by climate change? Given the sites in which Anthropocene narratives are confined and the tendency for these narratives to produce political inertia and moral ambiguity, can we create a conversation that examines how the Anthropocene intersects with specific communities without "overgeneralizing" the "social drivers and human consequences?"51 Is the Anthropocene narrative an ontological trap that legitimizes certain ways of thinking and ultimately consolidates power? Can we imagine a critical, anti-capitalist narrative that explores true questions of justice and morality in terms of both human and "non-human agencies"? 52

\section{New Directions: Multiply Activist Ways of Reclaiming ${ }^{53}$}

As humanities scholar Roy Scranton states, the future of "our collective existence" depends on our capacity to imagine a new socio-political reality. ${ }^{54}$ In order to adapt to the Anthropocene, "we're going to need [...] a new conceptual understanding of reality, and a new relationship to the deep polyglot traditions of human culture that carbon-based capitalism has vitiated through commodification and assimilation." ${ }^{55}$ Humanities and social science scholarship has already gone a long way in examining the relationships between humans, social systems, and ecology. This leaves us with the primary task of creating conditions for new imaginative possibilities and models for sharing alternative narratives that represent a plurality of perspectives and rhetorical formats. It is here that we see a role for the living archive.

In order to free the imagination we're going to need: a further exploration of the full scope of embodied "speculative and democratic practices" and local, community centric social responses to living in the Anthropocene; ${ }^{56}$ strategies to amplify voices of those outside western academia and those whose lives have been disrupted by ecological change; and practices that reflect the fact that ecological ontology is something that

\footnotetext{
50 John Bellamy Foster, "Trump and Climate Catastrophe." Monthly Review 68, no. 9 (2017). https://monthlyreview.org/2017/02/01/trump-and-climate-catastrophe/.

51 Lövbrand et al., "Who Speaks for the Future of Earth?" 214.

52 Lorimer, "Multinatural Geographies for the Anthropocene," 12.

53 The phrase "multiply activist ways of reclaiming" originated in this transcribed panel discussion: Latour, et al. "Anthropologists Are Talking-About Capitalism, Ecology, and Apocalypse," 591.

${ }^{54}$ Roy Scranton, Learning to Die in the Anthropocene: Reflections on the End of a Civilization (San Francisco, CA: City Lights Publishers, 2015), 19.

55 Ibid.

56 Lorimer, "The Anthropo-Scene: A Guide for the Perplexed," 133.
} 
"gains meaning through representational practices." 57 In light of this, we must actively create spaces to share and produce different kinds of media including art and ephemera representing alternative experiences and encompassing non-human perspectives to ensure that "other explanations of 'how we got to this point' and other proposals for 'what is to be done' may also have their say." ${ }^{58}$

\section{ARCHIVES IN THE ANTHROPOCENE}

If our existence in the Anthropocene is contingent on a reconceptualization of the broad and diverse voices of human culture, the archive may be the site where new imaginative possibilities emerge. However, these possibilities are contingent on whether we can reimagine the archive as a site that can produce socio-political and ecological change. An analysis of the Anthropocene alongside the archive reveals a shared problem, that of a narrative foreclosed by capitalism and by disciplinary and professional boundaries that we haven't been able to fully imagine our way out of.

\section{Origins of Archives \& Dominant Narratives}

Archives are laden with cultural baggage, manifesting as "monuments of states" ${ }^{59}$ that carry the sterility of government entities. ${ }^{60}$ Rather than serving the needs of the public, archives have been used throughout history by government authorities to construct narratives that serve goals of colonialism, nation-building, or the consolidation of power. ${ }^{61}$ Historically, the concept of the archive was "owned" by the discipline of history. ${ }^{62}$ Archival materials were thought to constitute the totality of valuable history in

57 Lövbrand et al., "Who Speaks for the Future of Earth?" 216.

${ }^{58}$ Bonneuil and Fressoz, The Shock of the Anthropocene, 49.

${ }^{59}$ Ann Laura Stoler, "Colonial Archives and the Arts of Governance," Archival Science 2 (2002): 90.

${ }^{60}$ Verne Harris, "Claiming Less, Delivering More: A Critique of Positivist Formulations on Archives in South Africa," Archivaria 44 (Fall 1997): 132-141.

61 Judy Barsalou, "Post-Mubarak Egypt: History, Collective Memory and Memorialization," Middle East Policy 19, no. 2 (2012): 134-147; Derrida, Archive Fever; Terry Cook, "Remembering the Future: Appraisal of Records and the Role of Archives in Constructing Social Memory," in Archives, Documentation, and Institutions of Social Memory: Essays from the Sawyer Seminar, eds. Francis X. Blouin and William G. Rosenberg (Ann Arbor: University of Michigan Press, 2006), 174; Charles Kecsckeméti, "Displaced European Archives: Is It Time for a Post-War Settlement?," American Archivist 55 (1992): 134; Matthew Kurtz, "A Postcolonial Archive? On the Paradox of Practice in a Northwest Alaska Project," Archivaria 61 (2006): 66, 89.

62 Theodore Schellenberg, "The Future of the Archival Profession," American Archivist 22, no. 1 (1959): 51. The first Archivist of the United States was a historian, and archivists emerged from the American Historical Association as a profession with its own Society of American Archivists 
ways that shape what is both knowable and authentic about the past. ${ }^{63}$ In reality, early "custodial" archives of the United States focused on collecting only the papers of prominent individuals and institutions, ${ }^{64}$ perpetuating "masculine iconization" and capitalist narratives of money and power while consistently leaving women, nonEuropeans, the economically marginalized, and similar groups out of the archival record. ${ }^{65}$ Such a system replicates the capital-based geographies of inequity and the power dynamics of geologic naming processes.

Critiques of the limitations of traditional archival institutions led to post-custodial praxis: changes in information creation, use, and dissemination models through the midtwentieth century challenged the storage limits of traditional archives, while public calls for government accountability expanded definitions of "records of governance" and resulted in a huge increase in what must be saved. ${ }^{66}$ Under the post-custodial model, public libraries, nonprofit organizations, and community members began to collect records outside official institutional archives while relying on traditional archival models and the expertise of trained archivists. ${ }^{67}$ In these contexts, post-custodialism reifies

in 1936, establishing its own standardized professional training programs. See: Robert M. Warner, "Archival Training in the United States and Canada," American Archivist, 3/4 (1972): 347-358.

${ }^{63}$ Derrida, Archive Fever; Cook, "Remembering the Future," 169; Flinn, "Community Histories, Community Archives: Some Opportunities and Challenges," Journal of the Society of Archivists, 28, no. 2 (2007): 152.

${ }^{64}$ Schellenberg, "The Future of the Archival Profession," 54.

65 Flinn, "Community Histories, Community Archives," 152; Purdom Lindblad, "Archives in the Anthropocene" (paper presented at the University of Houston Digital Humanities \& Social Justice Speaker Series and Workshops, Houston, TX, February 15, 2018); Moriah Ulinskas, "The Terezita Romo Papers: Capturing the Spirit of Collective Action in Archives," KULA: Knowledge Creation, Dissemination, and Preservation Studies 2, no. 1 (2018): 1, 8. This focus on archiving only a top-down perspective is not unique to North America, but is replicated in other regions. See Inge Bundsgaard and Michael H. Gelting, "What to Be or Not to Be? Evolving Identities for State and Grassroots Archives in Denmark," American Archivist 55 (1992): 49; Héctor J. MaymíSugrañes, "Latin American Archival Theory and Practice during the 1970s and 1980s," Libraries of Culture 34, no. 3 (1999): 226-227; Mónica Diaz, "The Indigenous Archive: Religion and Education in Eighteenth-Century Mexico," Hispanic Review (Spring 2018): 174-175; Mudney Halim, "The Westbury Community Archive: Claiming the Past, Defining the Present towards a Better Future," Education as Change 22, no. 2 (2018): 4.

${ }^{66}$ F. Gerald Ham, "Archival Strategies for the Post-Custodial Era," American Archivist 44, no. 3 (1981): 207; Cook, "Remembering the Future," 173.

${ }^{67} \mathrm{Ham}$, "Archival Strategies for the Post-Custodial Era," 212; Jimmy Zavala et al., "'A Process Where We're All at the Table': Community Archives Challenging Dominant Modes of Archival Practice," Archives and Manuscripts (2017): 209; Laél Hughes-Watkins, "Moving Toward a Reparative Archive: A Roadmap for a Holistic Approach to Disrupting Homogenous Histories in 
existing notions of professionalism and, in spite of placing collections more directly within communities, it does not reflect the multiple ways diverse communities have recorded and stewarded their history over time, nor does it allow for valuation of the dynamic cultural records that exist within living communities. ${ }^{68}$

\section{Politics of Archives}

The legacy of archival practice carries deep ties to racism, ${ }^{69}$ colonialism, ${ }^{70}$ abuses of power, ${ }^{71}$ economic corruption, ${ }^{72}$ sexism, and other processes of systematic erasure. Archives are burdened by these entrenched, often oppressive, institutional realities and yet they are simultaneously often viewed as value-free repositories staffed by archivists who are "neutral, invisible, silent handmaidens of historical research." ${ }^{13}$ This pretense of neutrality hinges on records themselves being value-free and non-political. ${ }^{74}$ In reality, insistence on neutrality only supports existing norms and reinforces representational

Academic Repositories and Creating Inclusive Spaces for Marginalized Voices," Journal of Contemporary Archival Studies 5 (2018): 6.

68 Jeannette A. Bastian, "The Records of Memory, the Archives of Identity: Celebrations, Texts and Archival Sensibilities," Archival Science 13, no. 2-3 (2013): 124.

69 Paul Gilroy, Ain't No Black in the Union Jack (Chicago, IL: University of Chicago Press, 1987) as referenced in Andrew Flinn, "Community Histories, Community Archives: Some Opportunities and Challenges," Journal of the Society of Archivists 28, no. 2 (2007): 151.

70 Mary Stevens, Andrew Flinn, and Elizabeth Shepherd, "New Frameworks for Community Engagement in the Archive Sector: From Handing over to Handing on," International Journal of Heritage Studies 16, nos. 1-2 (2010): 69.

${ }^{71}$ Stevens, Flinn, and Shepherd, "New Frameworks for Community Engagement," 61.

72 Andrew Flinn, "Community Histories, Community Archives," 152.

73 Cook, "Remembering the Future," 170; Diane K. Wakimoto, Christine Bruce, and Helen Partridge, "Archivist as Activist: Lessons from Three Queer Community Archives in California," Archival Science 13 (2013), 296; Alexandrina Buchanan and Michelle Bastian, "Activating the Archive: Rethinking the Role of Traditional Archives for Local Activist Projects," Archival Science 15 (2015): 429-451; Stevens, Flinn, and Shepherd, "New Frameworks for Community Engagement," 60; Hughes-Watkins, "Moving Toward a Reparative Archive," 4; Andrew Flinn, Mary Stevens, and Elizabeth Shepherd, "Whose Memories, Whose Archives? Independent Community Archives, Autonomy and the Mainstream," Archival Science 9 (2009): 73-74; Flinn, "Community Histories, Community Archives," 165; Andrew Flinn, "Independent Community Archives and Community-Generated Content: 'Writing, Saving and Sharing our Histories'," Convergence: The International Journal of Research into New Media Technologies 16, no. 1 (2010): 41.

74 Flinn, Andrew. "Community Histories, Community Archives"; Lindblad, "Archives in the Anthropocene." 
disparity and white privilege in archival holdings. ${ }^{75}$ The conceptualization of archives as static spaces that preserve nostalgic records of the past, with no impact on present and future and no role for archivists in the construction of social memory, denies the dynamic potential of archives beyond the implementation of new technology or expansion of collections.$^{76}$ This framework fails to acknowledge the transformative and productive role that archives can play in society. By collecting diverse narratives that can be "deconstructed and reconstructed" archives can re-activate social and political agency formerly stripped away by capitalism, and can provoke critical reflection on tools used in emancipatory struggles in order to reclaim individual and collective memory and create opportunities for performative action that enables new socio-economic possibilities. ${ }^{77}$

Post-custodial archiving has, in some cases, sought to correct representational disparities and colonial injustices through the repatriation of collections to rightful owners. 78 Such post-colonial practices are themselves fraught with internal contradiction: ${ }^{79}$ while the concept has helped to advance counter-narratives, the term can only exist in the context of a relationship to an oppressor, ${ }^{80}$ thereby perpetuating systems created by colonialism itself and, in some situations, creating new systems that

75 Mario Ramirez, "Being Assumed Not to Be: A Critique of Whiteness as an Archival Imperative," American Archivist 79, no. 2 (2015): 341; Melissa Adler and Lindsey M. Harper, "Race and Ethnicity in Classification Systems: Teaching Knowledge Organization from a Social Justice Perspective," Library Trends 67, no. 1 (2018): 57.

76 Flinn, "Community Histories, Community Archives" 160; Cook, "Remembering the Future," 169.

77 Mark A. Greene, "The Power of Meaning: The Archival Mission in the Postmodern Age," American Archivist 65 (2002): 55; Heidi Grunebaum, "Debates on Memory Politics and Counter-Memory Practices in South Africa in the 1990s," Education as Change 22, no. 2 (2018). 10-14; Tui Nicola Clery and Robin Metcalfe, "Activist Archives and Feminist Fragments: Claiming Space in the Archive for the Voices of Pacific Women and Girls," Education as Change 22, no. 2 (2018): 16; Joanna Newman, "Sustaining Community Archives," APLIS 25, no. 1 (2012); Flinn, Stevens, and Shepherd, "Whose Memories, Whose Archives?" 76, 83; Sonia Yaco et al., "A Web-Based Community-Building Archives Project: A Case Study of Kids in Birmingham 1963," Archival Science 15, no. 4: 402; Halim, "The Westbury Community Archive," 19.

78 Jeannette Allis Bastian, "A Question of Custody: The Colonial Archives of the United States Virgin Islands," American Archivist 64, no. 1 (2010): 96; Kimberly Christen, "Opening Archives: Respectful Repatriation," American Archivist 74 (Spring/Summer 2011): 185-210.

${ }^{79}$ Kurtz, "A Postcolonial Archive?" 65.

${ }^{80}$ Bastian, "The Records of Memory, the Archives of Identity," 124; Michelle Caswell, "Thank You Very Much, Now Give Them Back": Cultural Property and the Fight over the Iraqi Baath Party Records," American Archivist 74 (2011): 239-240. 
consolidate capital and power. ${ }^{81}$ This paradox mirrors the centering of "anthropos" in Anthropocene narratives that strive to de-center humans, as well as the ontological tension of counter-institutional and anti-capitalist narratives.

Archival practice has further constructed conditions for oppression through exclusionary policies of appraisal and description. ${ }^{82}$ Classification and organization systems for knowledge and historic artifacts are "the very substance of colonial politics;" 83 archival description standards serve to reinforce dominant norms and cultivate conformity across historic records. Knowledge organization schemas have consistently failed to provide ways of representation for communities and identities with less social status and power. ${ }^{84}$ As we reflected on the power of naming in theorization of the Anthropocene, we understand that archives wield this very power of naming and description.

While some archivists seek to right these past wrongs while working within existing institutions, ${ }^{85}$ others critique institutional spaces as sites that consolidate power, accumulate cultural material as capital, and perpetuate oppression. ${ }^{86}$ In light of this, some archivists have looked to extra-institutional community archives but face additional struggles: their sustainability depends on stable funding, and funding models often carry the power to shape what is collected, prioritized, and rendered visible in collections. ${ }^{87}$ Just as radical transformative politics that imagine alternative futures are threatened by those who value capitalism over climate, archives which re-center community are similarly threatened by capitalism.

${ }^{81}$ Kurtz, "A Postcolonial Archive?" 89; T-Kay Sangwand, "Preservation is Political: Enacting Contributive Justice and Decolonizing Transnational Archival Collaborations," KULA: Knowledge Creation, Dissemination, and Preservation Studies 2, no. 1 (2018): 3.

82 Kurtz, "A Postcolonial Archive?" 86.

83 Stoler, "Colonial Archives and the Arts of Governance," 92.

${ }^{84}$ Adler and Harper, "Race and Ethnicity in Classification Systems," 59; Laura Miller, "An Obligation of Trust: Speculations on Accountability and Description," American Archivist 69, no. 1 (2006): 68; Emily Drabinski, “Queering the Catalog: Queer Theory and the Politics of Correction," Library Quarterly: Information, Community, Policy 83, no. 2 (2013): 97; Ulinskas, "The Terezita Romo Papers," 1.

${ }^{85}$ Hughes-Watkins, "Moving Toward a Reparative Archive," 6.

${ }^{86}$ Flinn, "Community Histories, Community Archives," 151-152; Chaitra Powell et al., "This [Black] Woman's Work: Exploring Archival Projects that Embrace the Identity of the Memory Worker," KULA: Knowledge Creation, Dissemination, and Preservation Studies 2, no. 1 (2018): 2,5.

87 Bergis Jules, "Let the People Lead: Supporting Sustainability vs Dependency Models for Funding Community-Based Archives." 


\section{Contestation: Community Archives}

The practice of community archiving pre-exists its theorizing, yet an increased professional interest in how socially marginalized groups document, collect, and archive their own history led to the development of new practices to capture and share cultural heritage.$^{88}$ Community archives are related to post-custodial work in that they focus on community ownership of the archiving project. However, community archives are distinguished as sites where projects are initiated and practices are informed by the community itself. ${ }^{89}$ Community archives are rooted in a desire to document and preserve histories that "are often absent from mainstream archives and other heritage institutions" 190 with the foremost goal of ensuring communities maintain control over their own heritage in their own spaces. ${ }^{91}$

Some community archives projects receive substantial support from traditional institutional archives ${ }^{92}$ (others remain entirely independent), but all are set apart by a level of self-determination that is key to their work of documenting specific community histories from specific points of view. Many community archives work directly to counter the systems of oppression and cultures of exclusion outlined above. In community archives, we see collection policies and archival practices that: challenge dominant historic narratives through collection of diverse histories in diverse formats; ${ }^{93}$ counter

88 Stevens, Flinn, and Shepherd, "New Frameworks for Community Engagement," 65-69; Danielle Allard and Shawna Ferris, "Antiviolence and Marginalized Communities: Knowledge Creation, Community Mobilization, and Social Justice through a Participatory Archiving Approach," Library Trends 64, no. 2 (2015): 360;

${ }^{89}$ Flinn, "Community Histories, Community Archives," 153; Stevens, Flinn, and Shepherd, "New frameworks for community engagement," 60. Community archives function under a wide variety of labels, are created through a range of motivations, and stem from different conceptions of "community", but all share the basic value of community ownership.

90 Flinn, Stevens, and Shepherd, "Whose Memories, Whose Archives?" 73-76; Stevens, Flinn, and Shepherd, "New Frameworks for Community Engagement," 66; Michele Caswell, "Seeing Yourself in History: Community Archives and the Fight Against Symbolic Annihilation" The Public Historian 35, no. 4 (2014): 27; Rebecca T. Sheffield, “More than Acid-Free Folders: Extending the Concept of Preservation to Include the Stewardship of Unexplored Histories," Library Trends 64, no. 3 (2016): 576.

91 Joan Nestle, "The Will to Remember: The Lesbian Herstory Archives of New York," Feminist Review 34 (1990): 87

92 Andrew Flinn, “Independent Community Archives and Community-Generated Content," 41.

93 Wakimoto, Bruce, and Partridge, "Archivist as Activist," 303; Louise Craven, "From the Archivist's Cardigan to the Very Dead Sheep: What are Archives? What are Archivists? What do They Do?" in What are Archives?: Cultural and Theoretical Perspectives: A Reader, ed. Louise Craven (Farnham, UK: Ashgate Publishing, 2008): 8-9; Ajamu X, Topher Campbell, and Mary Stevens, "Love and Lubrication in the Archives, or rukus!: A Black Queer Archive for the United 
systems of appraisal and description that embed racist or otherwise harmful and limiting terminology and worldviews in our archives collections; ${ }^{94}$ involve community members in developing collection policies, organizational structures, and classification schemas regardless of their status on traditional scales of professionalism; ${ }^{95}$ investigate anti-racist and anti-colonial strategies for approaching history; ${ }^{96}$ work to disrupt hierarchical governance; ${ }^{97}$ and redistribute financial resources in ways that allow for communitydetermined sustainability. ${ }^{98}$

Just as critical approaches to the Anthropocene demand forward looking and community-centric responses, community archives theory advances participatory practices and representational frameworks that situate archives as transformative spaces. ${ }^{99}$ However, we must also acknowledge that attempts at representational transformation are often met with difficulty and criticism: financial capital dictates the

Kingdom," Archivaria 68 (2009): 280; Flinn, “Community Histories, Community Archives," 153, 155, 158, 164; Flinn, Stevens, and Shepherd, "Whose Memories, Whose Archives?" 79, 83;

Evelyn Wareham, "From Explorers to Evangelists: Archivists, Recordkeeping, and Remembering in the Pacific Islands," Archival Science 2 (2002): 198-199; Sheffield, "More than Acid-Free Folders," 579-580; Amanda Strauss, "Treading the Ground of Contested Memory: Archivists and the Human Rights Movement in Chile," Archival Science 15, no. 4 (2015): 369-397.

${ }^{94}$ Stacie M. Williams and Jarrett M. Drake, "Power to the People: Documenting Police Violence in Cleveland," Journal of Critical Library and Information Studies Special Issue: Critical Archival Studies 1, no. 2 (2017): 4; Michelle Caswell, "Teaching to Dismantle White Supremacy in Archives," The Library Quarterly 87, no. 3 (2017): 222-235; Sara A. Howard and Steven A. Knowlton, "Browsing through Bias: The Library of Congress Classification and Subject Headings for African American Studies and LGBTQIA Studies," Library Trends 67, no. 1 (2018): 85-86; Kurtz, "A Postcolonial Archive?" 67, 88.

95 Flinn, "Independent Community Archives and Community-Generated Content," 44-45; Yusef Omowale, "We Already Are," Sustainable Futures; Phil Cohen, Archive That, Comrade! Left Legacies and the Counter Culture of Remembrance (Oakland, CA: PM Press, 2018), 66, 76; Ulinskas, "The Terezita Romo Papers," 10; Sangwand, "Preservation is Political," 7-9.

96 Michelle Caswell, "Teaching to Dismantle White Supremacy in Archives," The Library Quarterly 87, no. 3 (2017); Cook, "Remembering the Future," 169; Jarrett M. Drake, "Liberatory Archives: Towards Belonging and Believing" (paper presented at the Liberatory Archives Forum, Los Angeles, CA, October 21, 2016).

97 Zavala et al., "'A Process Where We're All at the Table,'” 214.

${ }^{98}$ South Asian American Digital Archive, "Against Precarity: Towards a Community-Based Notion of Fiscal Sustainability," Sustainable Futures; Omowale, "We Already Are."; Interference Archive, "Sustainability at Interference Archive," Sustainable Futures.

99 Buchanan and Bastian, "Activating the Archive."; Michelle Caswell et al., "'To Be Able to Imagine Otherwise': Community Archives and the Importance of Representation," Archives and Records 38, no. 1 (2017); Michelle Caswell, Marika Cifor, and Mario H. Ramirez, " "To Suddenly Discover Yourself Existing": Uncovering the Impact of Community Archives," American Archivist 79, no. 1 (2016): 56-81. 
possibility of most community archiving projects, and forms of participatory archiving are seen by some as an "attack on professionalism" and a sacrifice for the archivist and the archives profession. ${ }^{100}$ This stance reflects the problems of austerity and cultural devaluation facing even government and institutional archives. The community archive makes space for the diverse voices that witness and respond to the Anthropocene, but can it free itself from the power structures that seek to consolidate capital, perpetuate oppression, and reinforce hierarchies of professionalism?

\section{New Directions}

If community archives, where alternative narratives might be housed and imaginative possibilities might be introduced, cannot move behind the limits of capitalism and professionalism then our task is to create a new model, a living archive. We imagine the living archive as a responsive, collaborative, and generative community space that counters existing systems of power and oppression, including the power encoded in professionalism. The term "living archive" is not new, and we build on descriptions of it as a site that is inclusive, is never complete, and in which the archivist is an "active participant" in constructing the history that is archived. ${ }^{101}$ The living archive is participatory and open, ${ }^{102}$ and has a more flexible, adaptive infrastructure that can aid in decolonization. ${ }^{103}$ The living archive is referenced in discussions of bodily representation of histories of individuals and communities suffering trauma and is used to counter the concept that published texts should be privileged in archives over living histories, bodily records, and imaginaries. The living archive is the "archive of feelings" that recognizes "bodies and memories of activist individuals and organisations [as] repositories for the stories of marginalised communities." ${ }^{104}$ The living archive acknowledges the emotional

${ }^{100}$ Andrew Flinn, "An Attack on Professionalism and Scholarship? Democratising Archives and the Production of Knowledge," Ariadne 62 (2010); Alexandra Margaret Mary Eveleigh, "Crowding out the Archivist? Implications of Online User Participation for Archival Theory and Practice" (PhD diss., University College of London, 2015), 58-59.

101 Stuart Hall, “Constituting an Archive," Third Text 15, no. 54 (Spring 2001): 92.

102 Susan Rudy, "The State of Knowledge about "Living Archives, New Media Archives," Sustaining Digital Scholarship for Sustainable Culture.

${ }^{103}$ Wareham, "From Explorers to Evangelists: Archivists, Recordkeeping, and Remembering in the Pacific Islands," 207.

104 Tui Nicola Clery and Robin Metcalfe, "Activist Archives and Feminist Fragments," 8; Horacio N. Roque Ramirez, "A Living Archive of Desire: Teresita la Campesina and the Embodiment of Queer Latino Community Histories," in Archive Stories: Facts, Fictions, and the Writing of History, ed. Antoinette Burton (Durham, NC: Duke University Press, 2006): 111 - 127; Ann Cvetkovich, An Archive of Feelings (Durham, NC: Duke University Press (2003); Ann Cvetkovich, "AIDS Activism and the Oral History Archive," The Scholar and Feminist Online 2, no. 1 (Summer 2003). http://sfonline.barnard.edu/ps/cvetkovi.htm; Amelia Acker, "How Cells 
complexity of activist history and ongoing social movement organizing, foregrounds living history, and represents an embodied and affective counterweight to apocalyptic Anthropocene narratives permeated with death and extinction. ${ }^{105}$

Much of this previous work on the living archive is grounded in the intersection of archives and affect theory as a means to understand the ways that experience, inclusivity, and performativity within the archive can play a role in disrupting rhetoric of whiteness, inviting plurality, and creating space for marginalized voices. ${ }^{106}$ Affect theory is suggested as a means to foster the cultivation of social justice in archives through a rejection of neoliberalism; however, in this analysis, no alternative economic or political model is provided. ${ }^{107}$ Affect theory also calls for a re-consideration of the relationship between the archivist and the creators, donors, users, and communities represented and served by the archive through the lens of radical empathy, yet we see across the community archives literature that divisions of professionalism are largely maintained. ${ }^{108}$ Elsewhere, affect theory has been used to conclude that archives have huge potential for "cultural production and politics" but that this "will require a scholarly engagement with the materiality of archival space to harness such potential." ${ }^{109}$

We believe in the value of documenting the emotional impact of history within archives and see the valuable work that affect theory does to move archives towards liberation. However, we look to move beyond notions that archives collections can accomplish transformative work through scholarly engagement, perpetuation of professional hierarchies, or apolitical rejection of neoliberal ideologies. Perhaps we can recover the archive (and its imaginative potential) if we center our community in our work and collapse distinctions between community members and archivists (who may or may

Became Records: Standardization and Infrastructure in Tissue Culture," Archival Science 15 (2015): 4; Anne J. Gilliland and Michelle Caswell, "Records and Their Imaginaries: Imagining the Impossible, Making Possible the Imagined," Archival Science 16 (2016): 72.

105 Cvetkovich, "AIDS Activism and the Oral History Archive."

${ }^{106}$ Marika Cifor, "Affecting Relations: Introducing Affect Theory to Archival Discourse," Archival Science 16 (2016): 21-22; Marika Cifor, "Stains and Remains: Liveliness, Materiality, and the Archival Lives of Queer Bodies," Australian Feminist Studies 32 nos. 91-92: 17.

107 Cifor, "Affecting Relations: Introducing Affect Theory to Archival Discourse," 23.

108 Michelle Caswell and Marika Cifor, "From Human Rights to Feminist Ethics: Radical Empathy in the Archives," Archivaria 81 (2016): 23-43. Sarah Welland's study on community archives serves as a clear example of the way language can create hierarchies and divisions against community archives, even while promoting better understanding of this work. By dividing research subjects into "experts" and "practitioners" - even while admitting that the "experts" have no expertise in community archives - we see that the "practitioners", or community archivists, are immediately stripped of their very real historic and community expertise by terminology alone. See Sarah Welland, "'Us and Them': Expert and Practitioner Viewpoints on Small New Zealand Community Archives," Information Research 22, no. 4 (2017): 1-12

${ }^{109}$ Cifor, "Stains and Remains: Liveliness, Materiality, and the Archival Lives of Queer Bodies," 18. 
not be credentialed), such that relationships do not need to be reconsidered through the lens of "us and them" but are understood as "we are all in this together." In the living archive we recognize the active role we all play in "in constructing social and historical memory," ${ }^{110}$ and cultivating spaces that are performative and generative. This kind of living archive looks beyond hegemonic methodologies and the limits of academic theorizing to emulate lived community practices in ways that systematically transform what and how we preserve, describe, access, and use information. The living archive might provide a path through the ontological murk of the Anthropocene and inspire new economic, political, and social relationships to the diverse (human and non-human) narratives of our world by reflecting and building upon current social responses to living in the Anthropocene, amplifying the voices of those outside academia, preserving human and non-human entities on the verge of extinction, constructing alternative socioeconomic ways of being in the world, and understanding the representational practices that give meaning to ecological ontology in our present era.

If the living archive is necessarily integrated into the social fabric of communities ${ }^{111}$ and imbued with the power to inspire action in the present moment, ${ }^{112}$ then each instance of the living archive must be a specific, culturally situated place. Within the context of particular oppressive systems and representational disparities, the living archive emerges as an activist strategy that (re)constructs reality ${ }^{113}$ through a cross section of information, community organizing, and radical history. As it interferes with and shapes ecological and political systems, the living archive becomes both a method for interrogating the past and "an irreducible experience of the future." 114

\section{RADICAL PRESENTS, ALTERNATIVE PASTS, REIMAGINED/REIMAGINING FUTURES}

\section{The Living Archive is Itself a Politics}

In practice, we see many radical, community-run, independent archives embracing principles of the living archive outlined above. We also believe archivists working in

\footnotetext{
${ }^{110}$ Cook, "Remembering the Future: Appraisal of Records and the Role of Archives in Constructing Social Memory," 170.

${ }^{111}$ Evans et al., "Self-determination and Archival Autonomy: Advocating Activism."

112 Barsalou, "Post-Mubarak Egypt: History, Collective Memory and Memorialization."

${ }^{113}$ Flinn, Stevens, and Shepherd, "Whose Memories, Whose Archives?" 76, 83; Yaco et al., "A Web-Based Community-Building Archives Project," 402; Flinn, "Community Histories, Community Archives: Some Opportunities and Challenges, " 159; Cook, "Remembering the Future: Appraisal of Records and the Role of Archives in Constructing Social Memory," 170. 114 Derrida, Archive Fever, 45.
} 
traditional institutions-in spite of (or perhaps because of) the limitations of these spaces - should work to integrate principles of the living archive into their praxis since institutional spaces play a central role in construction cultural memory and shaping the future. Archivists in any arena can begin by developing community partnerships; rejecting neutrality and remaining cognizant of the archive's positionality within oppressive structures; being intentional about the receipt of donations; understanding how capital influences collection acquisitions and processing and reflecting this in curatorial and descriptive practices; advocating for alternative access policies; and ensuring archival description standards reflect community rather than institutional priorities. The living archive (and its manifestation in real spaces) emerges from the specific community and cultural moment in which it exists - anthropocenic, yes, but also local and continually changing. For this reason, the final part of this essay focuses on one example, Interference Archive (IA), an independent, community-run archive in Brooklyn, New York with a mission to "explore the relationship between cultural production and social movements." 115 We believe this case study, integrated with principles from a living archive manifesto, captures what it looks like to move towards the goals of a living archive while also acknowledging the limitations of this space and the paradoxes it exists within. ${ }^{116}$

The work of IA manifests in an open stacks archival collection, publications, a study center, and public programs including exhibitions, workshops, talks, and screenings, all of which encourage critical and creative engagement with the rich history of social movements. ${ }^{117}$ As an archive of material produced by social movements around the world, IA exists at the cross-section of many disparate communities that share a unified goal to interfere with the status quo and to change the political, economic, and environmental systems in which they are enmeshed. By creating space for those who have been rendered invisible within and sidelined by extractive environmental, economic, and political systems, IA contributes to a counternarrative in which those exploited by industry and affected by ecological change gain social capital.

The material history represented in the IA collection provides a strategic framework, including the organizational tactics, ideas, lexicons, and symbols used in past social movements, which can be translated and adapted to serve the needs of ongoing contemporary struggles. IA programs, exhibitions, and community collaborations generate new narratives and cultural outputs outside the forum of the academy; they

\footnotetext{
115 “Our Mission," Interference Archive, https://interferencearchive.org/our-mission/ (accessed June 19, 2018).

116 Pieces of the manifesto are represented as subheadings for this case study. See Appendix 1 for full manifesto.

117 Ibid.
} 
help us build community, document and confront the challenges of living in the Anthropocene, and reimagine possible futures.

\section{The Living Archive is Not Neutral}

As volunteers at IA, we explore and work toward understanding the ways in which the space is enmeshed in ongoing movement struggles and also our own lives and communities. At IA, we have both been involved in administrative decision making, educational initiatives, developing and populating the online catalog, curating exhibitions, and planning events. Some of these projects are enumerated below. Our position-as theorizers of an archive that we are involved with-is one that we recognize as potentially fraught. However, we view archives and the social realities they reflect as spaces that we can never be truly outside of and it is from within this context that we write about and through our experiences.

\section{The Living Archive Enables Political Pluralism and Strives for Emancipation}

While IA has no singular political stance, the general ethos of its community leans towards different degrees of anti-authoritarianism and anti-capitalism; however, social movements from across the spectrum are represented in its collections. As a selfgoverned and self-managed entity, IA is an experiment in counter-institutional politics with a non-hierarchical operating structure that operates using consensus-based decision-making. IA's most powerful statement is that it continues to exist and grow, modelling new possibilities for archival spaces and practices.

\section{The Living Archive is an Alternative Formulation That Presents a Threat to Those Who Seek to Consolidate Power and Oppress Others}

On any given day of the week, one might walk into IA to find a range of activities and events taking place. These could include people discussing the status of the Environmental Protection Agency (EPA) superfund clean-up of a canal a few blocks away, or learning about radical mycology with a local fungi expert, or discussing the current political situation in Brazil over skype with local activists, or watching a film about the history of U.S. destabilization of democracy in Central America, or visiting from a local college to research intersections of design and social change, or packing up posters to give away at an anarchist book fair, or joining a discussion with an independent Mexican editor about publishing as a tool for resistance and movement-building, or reading poems 
aloud with a gathering of New York City domestic workers, or talking about a hypothetical universe in which refrigerators were never invented. ${ }^{118}$

\section{In the Living Archive, Everyone is an Archivist}

At IA, work is organized through a series of non-hierarchical interlocking working groups: Administration, Audio, Cataloging, Education, Born Digital, Staffing, and Exhibitions. This labor model has evolved over time in response to changing levels of community participation and changing priorities. Its non-hierarchical basis recognizes that all individuals, regardless of their wealth, educational level, or social status, have valuable skills that serve as the foundation for the archive's operations. The IA labor model also emulates the organizational structure of many of the social movements represented in the archive, which re-imagine internal social and power hierarchies as a way to reconceptualize larger socio-political dynamics. Current volunteers include retirees, highschool students, farmers, individuals with academic training as archivists and librarians, teachers, activists, service-industry workers, mothers, part-time contingent employees, performers, poets, labor organizers, artists, and more. Much of IA's enactment of its mission is driven by the particular interests of its volunteers, who chose to mount specific exhibitions, curate public programs, or work with specific collections. While community interests rather than capital determine priorities in our exhibitions and programs, this does not remove the problem of underrepresentation, but the community strives to acknowledge and fill gaps in our collections and programming.

\section{The Living Archive Relies on Funding Models That Don't Compromise Its Core}

\section{Values}

Operational funding of IA is provided by the community that uses the archive and that believes in its mission: over 100 individuals give between ten and fifty dollars each month; a donation jar is passed at all free public events to collect funds towards rent; and class visits from higher education institutions provide a revenue stream that diverts financial capital from large institutions. All labor is donated, and as such, all volunteers share ownership of IA in the same way that financial donors play a role in keeping the archive alive. Everyone literally is the archive. This funding model ultimately illustrates that anticapitalist and extra-institutional funding models are possible and sustainable. At the same time, this funding model means volunteers at IA do this work alongside the labor that pays rent and puts food on their tables, which creates limitations around who has the ability to participate.

118 "Events," Interference Archive. https://interferencearchive.org/category/events/ (accessed June 21, 2018). 


\section{The Living Archive is Social and Takes Up Space in the World}

IA is envisioned as a distinctly social space. Beyond the social relationships that form between volunteers, IA's open storefront in Brooklyn creates space for the cultivation of community networks. IA places emphasis on having physical space for human bodies to interact, with the understanding that these bodies, the social movements they are part of, and the physical culture they produce are all at the core of IA's archiving work. Part of the labor of IA is building relationships and the archive has collaborated with organizations, organizers, and agitators including: Occuprint, Mobile Print Power, Combat Paper NJ, Todos Somos Japon, Sublevarte Colectivo, Convergencia Grafica MALLA, Reverend Billy and the Church of Stop Shopping, Bread and Puppet Theater, sub.Media, El Rebozo Palapa Editorial, Poor People's Campaign, and more. IA's recent relocation in the fall of 2017 was spurred by a landlord's building sale, but it allowed for intentionality in the selection of a space that would be accessible for all, adhering to ADA guidelines and also advancing IA's belief that social movement organizing must be family-inclusive by providing adequate space for Radical Playdate programming.

\section{The Living Archive Creates Community and Aspires to Be a Nexus between}

\section{Communities}

Interference Archive has absorbed the print history of activist movements forced to relocate in the face of gentrification and displacement. When the Yippie House was evicted in 2013, IA took in a large portion of its underground newspaper collection, and similarly when the Peace Pentagon was sold in 2016, tenants including the War Resisters League and Paper Tiger Television donated large collections of material that they could not move to their new homes. At the same time, IA receives a constant flow of collection material from international organizers. Recent examples include a Dutch antiglobalization activist stopping by while in town to bring stickers from current campaigns, a countercultural space in Tokyo regularly mailing packages of material to IA; an activist from Spain visiting annually to bring material from squatting communities and antiausterity workers across Europe.

Much of this material comes to IA because it has not typically been preserved in other mainstream collections and, more critically, because the owners of this material feel that it will not be made adequately accessible if donated to larger institutions. At IA, items that represent lived experiences-zines, comics, underground newspapers, and films-are the most central part of our collection. IA also explores new ways to collect materials representing the ongoing struggles of the people in the surrounding community. A recent exhibition on grassroots anti-fascist organizing included a crowdsourced timeline of racist incidents that visitors to the archive had experienced or witnessed. 


\section{Conceptions of Permanence and Preservation Are Determined by Community Ideas and Intentions}

IA has a collection policy to focus on ephemeral materials (e.g., posters, pamphlets, flyers) produced in multiples for widespread distribution in support of social movement struggles. ${ }^{119}$ These kinds of materials are not traditionally archival and have not historically been valued by institutional spaces for either their formal qualities or academic merit. ${ }^{120}$ All material in the IA collection is donated. This community-generated collecting strategy means that the archive is only as complete as the community; it is necessary to continually work towards greater diversity and inclusion in order to have an archive community and collection that truly reflect the space we live and archive in, and IA is cognizant of its gaps in diversity, always working towards stronger relationships and collaboration with the breadth of individuals and groups living alongside us.

Understanding the ephemeral, public, and political nature of material in its collection, IA follows an open stacks policy of "use as preservation." ${ }^{121}$ While this means that the physical integrity of some items may be compromised by constant handling, this policy honors the original intent of creators who hoped to widely disseminate ideas and incite social change.

\section{The Living Archive Strives to Preserve and Understand Rather Than Collapse Difference}

Collections at IA are organized by format and within each format, by subject. This schema has evolved in response to observations of how community members access material, and co-location allows visitors to observe parallels in representational, visual, or rhetorical strategies used across temporal and geographic struggles. The physical arrangement of IA's collection brings together myriad voices in conversation with each other. While many traditional archives divide collections to preserve an authorial voice or particular provenance, co-locating disparate material recognizes political pluralism, preserves distinct cultural experiences, and promotes analytical nuance.

\footnotetext{
119 "Our Collection Policy," Interference Archive, https://interferencearchive.org/donate-materials/ (accessed June 19, 2018).

${ }^{120}$ For other conceptualizations of ephemeral geologic "archiving," see footnote 3.

${ }^{121}$ Alycia Sellie et al., "Interference Archive: A Free Space for Social Movement Culture," Archival Science 15, no. 4 (2015): 460.
} 
The Living Archive Changes How We Think About Relationships between the Past, Present, and Future

IA purposefully uses their space and programs to create a continuum between the past and present and to collectively reimagine possibilities for the future of the archive and the community. During an exhibition on Radical Left organizing in the 1970s, IA collaborated with Third World Newsreel for a screening of People's Firehouse \#1 (1979), a film about Polish Americans in Williamsburg who occupied a local firehouse to protest municipal austerity measures, alongside Voces De Fillmore (2016), which depicts families in South Williamsburg dealing with the impact of gentrification and the decrease of the neighborhood's Latinx and working class population. Activists from the 1970s firehouse occupation came to the event and were in dialogue with the filmmakers of Voces De Fillmore, instigating conversation about the power that communities have to shape their neighborhoods, as well as the potential of community media to tell stories in the past as well as in the present.

The Living Archive Cultivates Human Agency through Collaboration and Embodied Action

IA's exhibits are designed to highlight historical struggles and catalyze action. The 2015 exhibition We Won't Move: Tenants Organize in New York City explored the rich history of tenant organizing across the city and was designed in collaboration with a dozen current tenant organizing groups whose historic accomplishments and current goals were included in the exhibit. The exhibition ran concurrently with New York City's 2015 Real Rent Reform Campaign, and in addition to a series of events and workshops on tenant organizing, it created space for tenant groups to explore past tactics and generate new ideas for their current work. IA volunteers and tenant organizing groups produced an exhibition catalog which contained reproductions of ephemera dating back to the 1940s. The catalog served to contextualize ongoing struggles in relation to 50 years of organizing for housing justice in New York City and provided resources for current tenants. Reproducible graphics created for the catalog have been used by tenant organizers internationally. In 2016, seeking opportunities to continue conversations about housing justice and facing eviction after the building containing IA's collection was put up for sale by landlords, IA volunteers tabled at a community forum on anti-gentrification and displacement at the Brooklyn Museum. ${ }^{122}$

\footnotetext{
122 "We Won't Move: Tenants Organize in New York City," Interference Archive Exhibitions, https://interferencearchive.org/we-wont-move-tenants-organize-in-new-york-city/ (accessed June 21, 2018).
} 


\section{The Living Archive is Generative}

All of IA's programs seek to instigate more use of the collection and spur more activism and cultural production, which then ultimately produces more archives. ${ }^{123} \mathrm{IA}$ amplifies radical voices in wider arenas through knowledge creation events like Wikipedia edit-athons. At a two-part Feminist Urbanism Wikipedia workshop designed in collaboration with a local urban studies graduate student and Wikimedia NYC, participants including local urban planners, activists, and information workers used IA materials and theoretical texts on urban theory and feminism to develop a collective definition of feminist urbanism. ${ }^{124}$ Participants then outlined what an inclusive feminist city looks like and began writing a collaborative Wikipedia entry on Feminist Urbanism. The event not only served to produce new knowledge and address disparities of representation on Wikipedia, but also prompted a public debate within the Wikipedia community about how marginalized topics should be included in the encyclopedia. The Wikipedia feminist urbanism debate effectively moved a local conversation started at IA into an expansive, online environment, and resulted in a group of strangers sharing ideas and constructing knowledge collectively.

\section{The Living Archive is Performative and Makes Space for Non-Human Perspectives}

IA explores new ways of thinking about and expressing contemporary political and ecological realities. In a recent collaboration with ecological activists and artists, Anne Percoco and Ellie Irons, from the Next Epoch Seed Library (NESL) and the Environmental Performance Agency (EPA), IA co-hosted a "weed and seed" walk. While learning about the wild plants growing along the Gowanus Canal (a superfund site a few blocks away from the archive), collecting seeds, and producing a collaborative map, Irons and Percoco led us to question binaries between "native" and "invasive" plants, drew connections between global industrialization and plant migration patterns, and prompted us to imagine what the landscape might look like if humans never existed or suddenly disappeared. Following the walk, Percoco used materials from IA that incorporated plant imagery to lead a discussion about the cultural associations that these images carry and how such associations have been (or could be) used to drive social and political change.

IA also fosters opportunities to reconsider the ways that social reality is performatively constructed and how we might use performance to deconstruct and reimagine the world. In a fall 2018 collaboration with the UK based performance artist and scholar Hugh Sillitoe, IA hosted an absurd "(no)work(no)shop" series. Over the course

\footnotetext{
123 "Events Policy," Interference Archive, https://interferencearchive.org/events-policy/ (accessed June 21, 2018).

124 "Feminist Urbanism," Interference Archive Events, https://interferencearchive.org/feministurbanism/ (accessed June 21, 2018).
} 
of the 6-week series, in the pursuit of "total poetic liberation" and driven by the possibilities of nonsensical responses to nonsensical realities, we developed characters and creatures, let go of the social conventions typically observed by strangers in close proximity, and developed a public, performative intervention. The (no)work(no)shop introduced new ways of interacting and occupying space, enabled us to consider the world from the perspective of non-human characters, and represented a methodological departure by dispensing with political messaging and looking instead to the generative power of play.

\section{CONCLUSION}

The dominant narrative of the Anthropocene that leads to "political impotence," forecloses imaginative possibilities, and erodes individual agency is refuted by our own experiences described alongside the theory of the living archive. The counternarrative that a space like IA makes room for is one that stands in opposition to the ontologically fraught and insular Anthropocene narrative. Interference Archive is not a perfect space or system, but it is integrated with ongoing social movement struggles and actively shaped by community practices. The lesson IA's collections reveals is that all problems, even the ones born out of industrialization and capitalism or carried through the history of humanity, manifest as local problems that affect the lives of real people. The people surviving in and fighting against the realities of the Anthropocene are the friends we meet at IA: those who can't renew their visa under a new political regime, the neighbor who works three contingent jobs without health insurance, the domestic workers toiling inside the neighborhood apartments, the academics bogged down by institutional bureaucracy, and the small business owner driven out of the neighborhood by rising rents.

When we preserve these narratives and provide a space to organize against the forces that oppress and marginalize the people we live and work among, we contribute to a new narrative, reclaim agency in the face of the Anthropocene, and help to collectively imagine and move towards a different future. However, we understand that we are not working towards a moment of perfection and that the archival and anthropocenic narratives will (and must) continue to evolve. In the Anthropocene all sites are fraught, evolving, and paradoxical. And so, we live within capitalism while imagining anti-capitalist models, share ideas through scholarship while acknowledging the limits of scholarly discourse, and find in each new direction, new opportunities for critique. 


\section{APPENDIX 1: THE LIVING ARCHIVE MANIFESTO}

The living archive must be a specific, culturally situated place.

The living archive emerges as an activist strategy that (re)constructs reality through a cross section of information, community organizing, and radical history.

The living archive is both a method for interrogating the past and "an irreducible experience of the future." 125

The living archive is itself a politics.

The living archive is not neutral.

The living archive enables political pluralism and strives for emancipation.

The living archive is an alternative formulation that presents a threat to those who seek to consolidate power and oppress others.

In the living archive, everyone is an archivist.

The living archive relies on funding models that don't compromise its core values.

The living archive is social and takes up space in the world.

The living archive creates community and aspires to be a nexus between communities.

In the living archive conceptions of permanence and preservation are determined by community ideas and intentions.

The living archive strives to preserve and understand rather than collapse difference.

The living archive changes how we think about relationships between the past, present, and future.

The living archive cultivates human agency through collaboration and embodied action.

The living archive is generative.

The living archive is performative and makes space for non-human perspectives.

${ }^{125}$ Derrida, Archive Fever, 45. 


\section{BIBLIOGRAPHY}

Acker, Amelia. "How Cells Became Records: Standardization and Infrastructure in Tissue Culture." Archival Science 15 (2015): 1-24.

Adler, Melissa and Lindsey M. Harper. "Race and Ethnicity in Classification Systems: Teaching Knowledge Organization from a Social Justice Perspective." Library Trends 67, no. 1 (2018): 52-73.

Allard, Danielle, and Shawna Ferris. "Antiviolence and Marginalized Communities: Knowledge Creation, Community Mobilization, and Social Justice through a Participatory Archiving Approach." Library Trends 64, no. 2 (2015): 360-383.

Altvater, Elmar, Eileen Crist, Donna Haraway, Daniel Hartley, Christian Parenti, and Justin McBrien. Anthropocene or Capitalocene?: Nature, History, and the Crisis of Capitalism. Oakland, CA: PM Press, 2016.

Angus, lan. "Anthropocene Working Group: Yes a New Epoch has begun." Climate and Capitalism, January 9, 2016. https://climateandcapitalism.com/2016/01/09/anthropocene-working-groupyes-a-new-epoch-has-begun/.

-- - Facing the Anthropocene: Fossil Capitalism and the Crisis of the Earth System. New York: NYU Press, 2016.

Barsalou, Judy. "Post-Mubarak Egypt: History, Collective Memory and Memorialization." Middle East Policy 19, no. 2 (2012): 134-147.

Bastian, Jeannette Allis. "A Question of Custody: The Colonial Archives of the United States Virgin Islands." American Archivist 64, no. 1 (2010): 96-114.

- - . "The Records of Memory, the Archives of Identity: Celebrations, Texts and Archival Sensibilities." Archival Science 13, nos. 2-3 (2013): 121-131.

Bonneuil, Christophe and Jean-Baptiste Fressoz. The Shock of the Anthropocene: The Earth, History and Us. New York: Verso Books, 2016.

Buchanan, Alexandrina, and Michelle Bastian. "Activating the Archive: Rethinking the Role of Traditional Archives for Local Activist Projects." Archival Science 15 (2015): 429-451.

Bundsgaard, Inge and Michael H. Gelting. "What to Be or Not to Be? Evolving Identities for State and Grassroots Archives in Denmark." American Archivist 55 (1992): 46-57.

Caswell, Michelle. "“Thank You Very Much, Now Give Them Back": Cultural Property and the Fight over the Iraqi Baath Party Records" American Archivist 74 (2011): 211240. 
- - . "Seeing Yourself in History: Community Archives and the Fight Against Symbolic Annihilation." The Public Historian 35, no. 4 (2014): 26-37.

- - . "Teaching to Dismantle White Supremacy in Archives." The Library Quarterly 87, no. 3 (2017): 222-235.

Caswell, Michelle and Marika Cifor. "From Human Rights to Feminist Ethics: Radical Empathy in the Archives." Archivaria 81 (2016): 23-43.

Caswell, Michelle, Marika Cifor, and Mario H. Ramirez. "“To Suddenly Discover Yourself Existing": Uncovering the Impact of Community Archives." American Archivist 79 , no. 1 (2016): 56-81.

Caswell, Michelle, Alda Allina Migoni, Noah Geraci, and Marika Cifor. "'To Be Able to Imagine Otherwise': Community Archives and the Importance of Representation." Archives and Records 38, no. 1 (2017): 5-26.

Chakrabarty, Dipesh. "The Climate of History: Four Theses." Critical inquiry 35, no. 2 (2009): 197-222.

Christen, Kimberly. "Opening Archives: Respectful Repatriation." American Archivist 74 (2011): 185-210.

Cifor, Marika. "Affecting Relations: Introducing Affect Theory to Archival Discourse." Archival Science 16 (2016): 7-31.

- - . "Stains and Remains: Liveliness, Materiality, and the Archival Lives of Queer Bodies." Australian Feminist Studies 32, nos. 91-92 (2017): 5-21.

Cohen, Phil. Archive That, Comrade! Left Legacies and the Counter Culture of Remembrance. Oakland, CA: PM Press, 2018.

Clery, Tui Nicola and Robin Metcalfe. "Activist Archives and Feminist Fragments: Claiming Space in the Archive for the Voices of Pacific Women and Girls." Education as Change 22, no. 2 (2018): 1-29.

Cook, Terry. "Remembering the Future: Appraisal of Records and the Role of Archives in Constructing Social Memory." In Archives, Documentation, and Institutions of Social Memory: Essays from the Sawyer Seminar, edited by Francis X. Blouin and William G. Rosenberg, 169-181. Ann Arbor, MI: University of Michigan Press, 2006.

Craven, Louise. "From the Archivist's Cardigan to the Very Dead Sheep: What are Archives? What are Archivists? What do They Do?" In What are Archives?: Cultural and Theoretical Perspectives: A Reader, edited by Louise Craven, 7-31. Farnham, UK: Ashgate Publishing, 2008.

Crutzen, Paul J. "Geology of Mankind." Nature 415, no. 6867 (2002): 23. 
Cvetkovich, Ann. An Archive of Feelings. Durham, NC: Duke University Press, 2003.

- - "AIDS Activism and the Oral History Archive." The Scholar and Feminist Online 2, no. 1 (Summer 2003). http://sfonline.barnard.edu/ps/printacv.htm (accessed March 24, 2019).

Davis, Robert. "Inventing the Present: Historical Roots of the Anthropocene." Earth Sciences History 30, no. 1 (2011): 63-84.

Diaz, Mónica. "The Indigenous Archive: Religion and Education in Eighteenth-Century Mexico." Hispanic Review (Spring 2018): 167-183.

Derrida, Jacques. Archive Fever: A Freudian Impression. Chicago, IL: The University of Chicago Press, 1996.

Drabinski, Emily. "Queering the Catalog: Queer Theory and the Politics of Correction." Library Quarterly: Information, Community, Policy 83, no. 2 (2013): 94-111.

Drake, Jarrett M. "Liberatory Archives: Towards Belonging and Believing." Presentation at the Liberatory Archives Forum, Los Angeles, CA, October 21, 2016, https://medium.com/on-archivy/liberatory-archives-towards-belonging-andbelieving-part-1-d26aaeb0edd1

Ellis, Erle, Mark Maslin, Nicole Boivin, and Andrew Bauer. "Involve Social Scientists in Defining the Anthropocene." Nature News 540, no. 7632 (2016): 192-193.

Ellis, Michael A., and Zev Trachtenberg. "Which Anthropocene is it to Be? Beyond Geology to a Moral and Public Discourse." Earth's Future 2, no. 2 (2014): 122125.

"Events." Interference Archive. Accessed June 21, 2018. http://interferencearchive.org/category/events/

"Events Policy." Interference Archive. Accessed June 21, 2018. http://interferencearchive.org/events-policy/

Evans, Joanne, Sue McKemmish, Elizabeth Daniels, and Gavan McCarthy. "Selfdetermination and Archival Autonomy: Advocating Activism." Archival Science 15, no. 4 (2015): 337-368.

Eveleigh, Alexandra Margaret Mary. Crowding out the Archivist? Implications of Online User Participation for Archival Theory and Practice. PhD Diss., University College of London, 2015.

"Feminist Urbanism," Interference Archive Events. Accessed June 21, 2018. http://interferencearchive.org/feminist-urbanism/ 
Flinn, Andrew. "Community Histories, Community Archives: Some Opportunities and Challenges." Journal of the Society of Archivists, 28, no. 2 (2007): 151-176. DOI: 10.1080/00379810701611936.

- - . "An Attack on Professionalism and Scholarship? Democratising Archives and the Production of Knowledge." Ariadne 62 (2010). http://www.ariadne.ac.uk/issue62/flinn/.

- - . "Independent Community Archives and Community-Generated Content 'Writing, Saving and Sharing our Histories.'" Convergence: The International Journal of Research into New Media Technologies 16, no. 1 (2010): 39-51.

- - - "Archival Activism: Independent and Community-led Archives, Radical Public History and the Heritage Professions." InterActions: UCLA Journal of Education and Information Studies 7, no. 2 (2011).

Flinn, Andrew, Mary Stevens, and Elizabeth Shepherd. "Whose Memories, Whose Archives? Independent Community Archives, Autonomy and the Mainstream." Archival Science 9 (2009): 71-86.

Foster, John Bellamy. "Marxism in the Anthropocene: Dialectical Rifts on the Left." International Critical Thought 6, no. 3 (2016): 393-421.

- - . "Trump and Climate Catastrophe." Monthly Review 68, no. 9 (2017): 1-17. https://monthlyreview.org/2017/02/01/trump-and-climate-catastrophe/.

Gilbert, Scott F., Jan Sapp, and Alfred I. Tauber. "A Symbiotic View of Life: We have Never been Individuals." The Quarterly Review of Biology 87, no. 4 (2012): 325341.

Gilliland, Anne J. and Michelle Caswell. "Records and Their Imaginaries: Imagining the impossible, making possible the imagined." Archival Science 16 (2016): 53-75.

Gilroy, Paul. Ain't No Black in the Union Jack. Chicago, IL: University of Chicago Press, 1987.

Godoy, Eric S. and Aaron Jaffe, "We Don't Need a 'War' on Climate Change, We Need a Revolution." [Op-ed] New York Times, Oct 31, 2016. https://www.nytimes.com/2016/10/31/opinion/we-dont-need-a-war-onclimate-change-we-need-a-revolution.html (accessed March 24, 2019).

Greene, Mark A. "The Power of Meaning: The Archival Mission in the Postmodern Age." American Archivist 65 (2002): 42-55.

Grunebaum, Heidi. "Debates on Memory Politics and Counter-Memory Practices in South Africa in the 1990s." Education as Change 22, no. 2 (2018): 1-19. 
Halim, Mudney. "The Westbury Community Archive: Claiming the Past, Defining the Present towards a Better Future." Education as Change 22, no. 2 (2018).

Hall, Stuart. "Constituting an Archive." Third Text, 15, no. 54 (2001): 89-92.

Ham, F. Gerald. "Archival Strategies for the Post-Custodial Era." American Archivist 44, no. 3 (1981): 207-216.

Hamilton, Clive. "Getting the Anthropocene so Wrong." The Anthropocene Review 2, no. 2 (2015): 102-107.

Harris, Verne. "Claiming Less, Delivering More: A Critique of Positivist Formulations on Archives in South Africa." Archivaria 44 (1997), 132-141.

Howard, Sara A. and Steven A. Knowlton. "Browsing through Bias: The Library of Congress Classification and Subject Headings for African American Studies and LGBTQIA Studies." Library Trends 67, no. 1 (2018): 74-88.

Hughes-Watkins, Lae'l. "Moving Toward a Reparative Archive: A Roadmap for a Holistic Approach to Disrupting Homogenous Histories in Academic Repositories and Creating Inclusive Spaces for Marginalized Voices." Journal of Contemporary Archival Studies 5 (2018). https://elischolar.library.yale.edu/jcas/vol5/iss1/6.

Interference Archive. "Sustainability at Interference Archive." Community Archives Sustainable Futures. https://medium.com/community-archives/sustainabilityat-interference-archive-4c33ebed69d8 (accessed December 5, 2018).

Jules, Bergis. "Let the People Lead: Supporting Sustainability vs Dependency Models for Funding Community-Based Archives." On Archivy: Occasional Writings about the Archive. https://medium.com/on-archivy/let-the-people-lead-supportingsustainability-vs-dependency-models-for-funding-community-based$82 \mathrm{f7} 6 \mathrm{~d} 54 \mathrm{c} 483$.

Kecsckeméti, Charles. "Displaced European Archives: Is It Time for a Post-War Settlement?" American Archivist 55 (1992): 132-140.

Kurtz, Matthew. "A Postcolonial Archive? On the Paradox of Practice in a Northwest Alaska Project." Archivaria 61 (2006): 63-90.

Latour, Bruno. "Anthropocene Lecture." Lecture, Haus der Kulturen der Welt, Berlin, Germany, May 4, 2018. https://www.youtube.com/watch?v=UtaEJo-jo8Q.

Latour, Bruno, Isabelle Stengers, Anna Tsing, and Nils Bubandt. "Anthropologists Are Talking-About Capitalism, Ecology, and Apocalypse." Ethnos 83, no. 3 (2018): 587-606.

Lewis, Simon L., and Mark A. Maslin. "A Transparent Framework for Defining the Anthropocene Epoch." The Anthropocene Review 2, no. 2 (2015): 128-146. 
Lindblad, Purdom. "Archives in the Anthropocene." Paper presented at the University of Houston Digital Humanities \& Social Justice Speaker Series and Workshops, Houston, TX, February 15, 2018.

Lorimer, Jamie. "The Anthropo-Scene: A Guide for the Perplexed." Social Studies of Science 47, no. 1 (2017): 117-142.

- - - "Multinatural Geographies for the Anthropocene." Progress in Human Geography 36, no. 5 (2012): 593-612.

Lövbrand, Eva., Silke Beck, Jason Chilvers, Tim Forsyth, Johan Hedrén, Mike Hulme, Rolf Lidskog, and Eleftheria Vasileiadou. "Who Speaks for the Future of Earth? How Critical Social Science Can Extend the Conversation on the Anthropocene." Global Environmental Change 32 (2015): 211-218.

Malm, Andreas, and Alf Hornborg. "The Geology of Mankind? A Critique of the Anthropocene Narrative." The Anthropocene Review 1, no. 1 (2014): 62-69.

Maymí-Sugrañes, Héctor J. "Latin American Archival Theory and Practice during the 1970s and 1980s." Libraries of Culture 34, no. 3 (1999): 222-440.

Miller, Laura. "An Obligation of Trust: Speculations on Accountability and Description." American Archivist 69, no. 1 (2006): 60-78.

Moore, Jason W. Capitalism in the Web of Life: Ecology and the Accumulation of Capital. New York: Verso Books, 2015.

Nestle, Joan. "The Will to Remember: The Lesbian Herstory Archives of New York." Feminist Review 34 (1990): 86-94.

Newman, Joanna. "Sustaining Community Archives." APLIS 25, no. 1 (2012): 37-45.

O'Brien, Karen, and Jon Barnett. "Global Environmental Change and Human Security." Annual Review of Environment and Resources 38 (2013): 373-391.

Omowale, Yusef. "We Already Are." Community Archives - Sustainable Futures. https://medium.com/community-archives/we-already-are-52438b863e31 (accessed December 5, 2018).

"Our Collection Policy." Interference Archive. https://interferencearchive.org/donatematerials/ (accessed June 19, 2018).

“Our Mission." Interference Archive. https://interferencearchive.org/our-mission/ (accessed June 19, 2018)

Powell, Chaitra, Holly Smith, Shanee Murrain, and Skyla Hearn. "This [Black] Woman's Work: Exploring Archival Projects that Embrace the Identity of the Memory Worker." KULA: Knowledge Creation, Dissemination, and Preservation Studies 2, no. 1 (2018). DOI: http://doi.org/10.5334/kula.25. 
Purdy, Jedediah. After Nature: A Politics for the Anthropocene. Cambridge, MA: Harvard University Press, 2015.

Ramirez, Horacio N. Roque. "A Living Archive of Desire: Teresita la Campesina and the Embodiment of Queer Latino Community Histories." In Archive Stories: Facts, Fictions, and the Writing of History, edited by Antoinette Burton, 111-127. Durham, NC: Duke University Press, 2006.

Ramirez, Mario. "Being Assumed Not to Be: A Critique of Whiteness as an Archival Imperative." American Archivist 79, no. 2 (2015): 339-356.

Rudy, Susan. "The State of Knowledge about "Living Archives, New Media Archives." Sustaining Digital Scholarship for Sustainable Culture. http://sustainableknowledgeproject.blogspot.com/2010/10/state-ofknowledge-about-living.html (accessed December 17, 2018).

Sangwand, T-Kay. "Preservation is Political: Enacting Contributive Justice and Decolonizing Transnational Archival Collaborations." KULA: Knowledge Creation, Dissemination, and Preservation Studies 2, no. 1 (2018). DOI: http://doi.org/10.5334/kula.36.

Schellenberg, Theodore. "The Future of the Archival Profession." American Archivist 22, no. 1 (1959): 49-58.

Scranton, Roy. Learning to Die in the Anthropocene: Reflections on the End of a Civilization. San Francisco, CA: City Lights Publishers, 2015.

Sellie, Alycia, Jesse Goldstein, Molly Fair, and Jennifer Hoyer. "Interference Archive: A Free Space for Social Movement Culture." Archival Science 15, no. 4 (2015): 453472.

Sheffield, Rebecca T. "More than Acid-Free Folders: Extending the Concept of Preservation to Include the Stewardship of Unexplored Histories." Library Trends 64, no. 3 (2016): 572-584.

South Asian American Digital Archive. "Against Precarity: Towards a Community-Based Notion of Fiscal Sustainability." Community Archives - Sustainable Futures. https://medium.com/community-archives/against-precarity-towards-acommunity-based-notion-of-fiscal-sustainability-815d1d889309 (accessed December 20, 2018).

Strauss, Amanda. "Treading the Ground of Contested Memory: Archivists and the Human Rights Movement in Chile." Archival Science 15, no. 4 (2015): 369-397. 
Steffen, Will, Jacques Grinevald, Paul Crutzen, and John McNeill. "The Anthropocene: Conceptual and Historical Perspectives." Philosophical Transactions of the Royal Society of London A: Mathematical, Physical and Engineering Sciences 369, no. 1938 (2011): 842-867.

Stevens, Mary, Andrew Flinn, and Elizabeth Shepherd. "New Frameworks for Community Engagement in the Archive Sector: From Handing over to Handing on." International Journal of Heritage Studies 16, nos. 1-2 (2010): 59-76.

Stoler, Ann Laura. "Colonial Archives and the Arts of Governance." Archival Science 2 (2002): 87-109.

Taylor, Jesse Oak. "Auras and Ice Cores: Atmospheric Archives and the Anthropocene." Minnesota Review 83, no. 1 (2014): 73-82.

Thomas, Julia Adeney. "History and Biology in the Anthropocene: Problems of Scale, Problems of Value." The American Historical Review 119, no. 5 (2014): 15871607.

Toivanen, Tero, Karoliina Lummaa, Antti Majava, Paavo Järvensivu, Ville Lähde, Tere Vaden, and Jussi T. Eronen. "The Many Anthropocenes: A Transdisciplinary Challenge for the Anthropocene Research." The Anthropocene Review 4, no. 3 (2017): 183-198.

University of Wisconsin. "Society of American Archivists Records, 1935-2017." Archival Resources in Wisconsin: Descriptive Finding Aids. http://digicoll.library.wisc.edu.

Ulinskas, Moriah. "The Terezita Romo Papers: Capturing the Spirit of Collective Action in Archives." KULA: Knowledge Creation, Dissemination, and Preservation Studies 2, no 1 (2018). DOI: http://doi.org/10.5334/kula.22.

Wakimoto, Diane K., Christine Bruce, and Helen Partridge. "Archivist as Activist: Lessons from Three Queer Community Archives in California." Archival Science 13 (2013): 293-316.

Wareham, Evelyn. "From Explorers to Evangelists: Archivists, Recordkeeping, and Remembering in the Pacific Islands." Archival Science 2 (2002): 187-207.

Warner, Robert M. "Archival Training in the United States and Canada." American Archivist 3/4 (1972): 347-358.

Welland, Sarah. "'Us and them': expert and practitioner viewpoints on small New Zealand community archives." Information Research 22, no. 4 (2017): 1-12.

"We Won't Move: Tenants Organize in New York City." Interference Archive Exhibitions. http://interferencearchive.org/we-wont-move-tenants-organize-in-new-yorkcity/ (accessed June 21, 2018). 
Williams, Stacie M., and Jarrett M. Drake. "Power to the People: Documenting Police Violence in Cleveland." Journal of Critical Library and Information Studies Special Issue: Critical Archival Studies 1, no. 2 (2017). DOI:

https://doi.org/10.24242/jclis.v1i2.33.

$\mathrm{X}$, Ajamu, Topher Campbell, and Mary Stevens. "Love and Lubrication in the Archives, or rukus!: A Black Queer Archive for the United Kingdom." Archivaria 68 (2009): 271-294.

Yaco, Sonia, Ann Jimerson, Laura Anderson and Chandra Temple. "A web-based community-building archives project: A case study of Kids in Birmingham 1963." Archival Science 15(4): 399-427.

Zavala, Jimmy, Alda Allina Migoni, Michelle Caswell, Noah Ceraci, and Marika Cifor. "'A Process Where We're All at the Table': Community Archives Challenging Dominant Modes of Archival Practice." Archives and Manuscripts (2017): 202215.

Zalasiewicz, Jan, et al. "What is the Anthropocene? Current Definition and Status." Working Group on the Anthropocene. Subcommission on Quaternary Stratigraphy Website. http://quaternary.stratigraphy.org/workinggroups/anthropocene/ (accessed December 20, 2018).

Zalasiewicz, Jan, Mark Williams, Alan Smith, Tiffany L. Barry, Angela L. Coe, Paul R. Bown, Patrick Brenchley, David Cantrill, Andrew Gale, Philip Gibbard, F. John Gregory, Mark W. Hounslow, Andrew Craig Kerr, Paul Nicholas Pearson, Robert Knox, John Powell, Colin Waters, John Marshall, Michael Oates, Peter Rawson, and Philip Stone. "Are We Now Living in the Anthropocene?" GSA Today 18, no. 2 (2008): 4-8. 